\title{
Politics of Mattering in the Practices of Participatory Design
}

\author{
Suvi Pihkala \\ Gender Studies \\ University of Oulu \\ Finland \\ suvi.pihkala@oulu.fi
}

\author{
Helena Karasti \\ INTERACT Research Unit \\ University of Oulu \\ Finland \\ helena.karasti@oulu.fi
}

\begin{abstract}
In this paper, ${ }^{1}$ we join those in the field of Participatory Design (PD) that have become inspired by the "ontological turn" as captured in the proliferating discussions around relationality, becoming, and nonhuman agency. The paper offers an account from a PD case where a social media platform was designed with and by professionals for their collaboration around the topic of workplace bullying and harassment. Through this account, this paper reimagines PD in a "posthuman landscape" and explores how this ontological turn forces-and/or enables-a rethinking of ethics and politics in PD. In a timely conference which asks for scrutinizing the ways that the political heritage of democracy, participation, and equality can be enacted in the diverse terrains of $\mathrm{PD}$, our short paper proposes the "politics of mattering" as a way of accounting for the design process as an always-relational becoming and its practices as already-political.
\end{abstract}

\section{CCS CONCEPTS}

- Human-centered computing $\rightarrow$ Interaction Design $\rightarrow$ Participatory design.

\section{KEYWORDS}

Becoming; ethics; feminist theory; matter; mattering; new materialism; Participatory Design; politics; posthuman; relationality; socio-materiality.

\section{ACM Reference format:}

S. Pihkala and H. Karasti. 2018. Politics of Mattering in the Practices of Participatory Design. In Proceedings of the 15th Participatory Design Conference - Volume 2, August 20-24, 2018, Hasselt and Genk, Belgium (PDC'18). DOI: xxxxxxxx.Xxxxxxxxxxx

\section{INTRODUCTION}

\footnotetext{
${ }^{1}$ Permission to make digital or hard copies of all or part of this work for personal or classroom use is granted without fee provided that copies are not made or distributed for profit or commercial advantage and that copies bear this notice and the full citation on the first page. Copyrights for components of this work owned by others than ACM must be honored. Abstracting with credit is permitted. To copy otherwise, or republish, to post on servers or to redistribute to lists, requires prior specific permission and/or a fee. Request permissions from Permissions@acm.org.

PDC '18, August 20-24, 2018, Hasselt and Genk, Belgium @ 2018 Association for Computing Machinery. ACM ISBN 978-1-4503-5574-2/18/08...\$15.00 https://doi.org/Xxxxxx.xxxxxxxx
}

Over the past years, scholars in varied fields have become increasingly enticed by the "ontological turn" captured in process ontologies [1], and in the posthuman and new materialist theories of becoming, relationality, affect, and nonhuman agency [2]. In design fields, these discussions have connected to the nuanced understandings of socio-materiality and the situatedness of human practice [3-6], the understandings of design as processual and becoming [7], the expansion from designing technologies only to "infrastructuring" $[8,9]$, and design with and for communities and publics $[10,11]$. The opening up to nonhuman agency has helped to negotiate the co-constitutive nature of "Things", issues, and matters of concern [12-14], and the consequent implications for design practices $[8,11]$. Others have considered these relational and entangled ontologies in order to renegotiate ethics, politics, and values in designing [11, 15-17]. Recently, Lindström and Ståhl $[18,19]$ explored ways of inviting "response-able" stakeholders in PD, and Light and Akama [7, 20, 21] have prompted "human touch" and social relations in PD practice that are not only bound to what is, but also to what is becoming and in-between. There is a willingness to open up to the world in its complex relationality, responsible and accountable for the open-ended and unexpected.

Our aim in this paper is to explore the potentialities of this relational thinking for $\mathrm{PD}$. Our discussion is based on our PD case that was one of four pilot case studies in a large research project on the use of social media in the field of workplace safety and well-being in Finland [22]. The first author was immersed in our case study as a designer-researcher for a period of a year and a half working closely with a group of user-practitioners [15] to collaboratively design a novel mode of collaboration and a network for them to learn and discuss workplace well-beingparticularly the concerns, practices, and experiences related to workplace bullying and harassment. The second author was engaged in the process through interdisciplinary dialogue with the first author as we have discussed in $[15,23]$.

In this paper, thinking through our case, our aim is to explore $\mathrm{PD}$ practices as always-relational socio-material entanglements and, inspired by the call for papers of this conference, discuss the ways in which the ontological turn prompts and enables PD community to rethink and reposition ethics and politics in PD.

In thinking about our case, we focus on the phenomenon of workplace bullying and explore how it mattered and reconfigured in and through our PD process. We focus on relationality and becoming and show how we can begin to see ethics and politics in new ways, as being always already 
ingrained in the process and practices of design. We begin with an introduction on this relational thinking, which will then accompany us in rethinking "politics of mattering" in our case.

\section{A POSTHUMAN LANDSCAPE}

Our theoretical thinking is inspired by what could be understood to be part of a posthuman or new materialist landscape [2]. The works in these landscapes originate from turns to ontology, materiality, and affect, and connect scholars such as Bruno Latour [24], Gilles Deleuze and Félix Guattari [25], and Karen Barad [26]. The proposals made by these scholars challenge to turn away from subject-object and mind-matter dualisms, which become replaced by relationality and becoming [2]. Our approach to these concepts is inspired particularly by feminist theorists Karen Barad [26] and Donna Haraway [27, 28].

For Barad, the world is an ongoing motion of mattering where subjects and objects do not pre-exist their relatings, but rather, come to matter through the ongoing interaction-or intra-action-of ontologically inseparable entities [26]. This is a relational thinking where matter comes to matter through the ongoing intra-acting entanglement of space, time, and matter, or "spacetimemattering" [26], as moments, places, or things do not exist independently, but rather are ontologically entangled.

The understanding of matter coming to matter through intraaction has radical implications on accountability and responsibility. Here Barad and Haraway, from their own entry points, propose a radical rethinking of ethics that foregrounds ethics as incarnate relations of response that precede intentionality-"response-ability" [26-29]. According to Barad and Haraway, we are always already ethically implicated through our ontological entanglements with the ongoing intraaction of space, time, and matter. Responsibility is about accountability for the mattering of our practices, i.e. for the possibilities and impossibilities that we co-constitute through our ontological entangledness within the world, as Barad [26] writes. This calls for the accountability for the mattering of our practices, as well as responsibility for specific, more livable worlds [26-29].

By focusing on the motion of mattering, we shift from attending to the socio-material as a background or a context in which things occur, to understanding it as entanglements of constantly reconfiguring forces through which things and issues come to matter. This thinking situates "us" human beings in the ongoing motion of mattering, and challenges to rethink ethics and politics in the middle of this complex relationality. In the following, we take this thinking of relationality and becoming and its ethico-political imprint as our starting point as we move on to our own PD case and, specifically, workplace bullying and harassment as its objects of concern.

\section{HOW WORKPLACE BULLYING AND HARASSMENT CAME TO MATTER?}

In the following, we provide three fragments that capture the phenomenon of workplace bullying and harassment as it reconfigured in our PD case. Our approach is based on the designer-researcher's engagement with the flow of the design process [15]. This is an approach that resonates with emerging voices in PD that have sought "relational sensitivity" and "ways of noticing" the between-ness-or $M a$, as discussed by Akama [21]-beyond sedimented categories and structures [7, 15, 16, 20]. However, in addition to reporting on our engagement then-andthere, we also include our return to the case after the project took place.

The first fragment focuses on invitations as a point of orientation for thinking about the design process with bullying and harassment as its objects of concern. By concentrating on being invited and included, we illustrate how "what already was" mattered in "what got to come to matter." The second fragment focuses on the collaboration among the user-practitioners and their work with authentic stories of bullying. We illustrate how the phenomenon of workplace harassment is reconfigured as the object of collaboration to be supported by social media in the complex entanglements of affects, histories, discourses, and materiality. The final fragment re-stories the case by focusing on open-endedness and partiality in the ongoing motion of mattering by extending to consider the times after the project.

At the heart of our stories is the phenomenon of workplace bullying and harassment as it reconfigured and mattered in the design process, and how the PD practices with their ethicopolitical premises reconfigured in this motion of mattering as well.

\subsection{Non-Innocent Beginning: Being Included}

The first author was invited to join one of the four pilot case studies which was conducted together with a study center-an educational service provider for particular trade unions in Finland. The pilot was introduced to the designer-researcher as a case for developing a social media platform to enable mutual learning about bullying and harassment in the workplaces to support workplace safety and well-being.

During the first few meetings with the study center as the key collaborator, discussions were carried out about who else should be included in this process and, more particularly, who should be invited into a set of workshops organized to envision and plan the future collaboration and the uses of social media for this purpose. During these discussions, the participants drew lists of those involved with the topic of workplace harassmente.g., victims, perpetrators, researchers, occupational physicians, and public officials-on a flipchart as a way of visualizing the different stakeholders.

Despite the acknowledgement of the varied stakeholders, the invitation was limited to a group of union professionals familiar to the study center. The choice as to those to be included ended up being partially a convenience to prolong the study center's existing collaborations, and partially to effect an "easy start" and to "get something done." While the designer-researcher's orientation would have been to open up bullying as a phenomenon to diverse voices, including those of the victims, the key collaborators, reflecting on years of experience, were wary of the possibilities for conflict. It is not only that bullying, 
as such, is affectively charged, but the very practices of interventions are enmeshed in conflict and contestation and entangled in the power, hierarchies and politics of the workplace.

Although the ethical and political challenge of "creating a better working life," as well as the principle of doing so democratically while respecting polyvocality, were iterated as shared values, they became reconfigured in the flow of the events. They were easy to maintain as principles when mapping the list of stakeholders, but when those lists became reanimated with the everyday experiences of interventions, the ways in which polyvocality could be cultivated began to appear more troubling. They also became entangled with convenience-the practical frames of getting on with the project's diverse and technologically inspired goals-and, consequently, materialized in the invitations. The idea of opening up to include "the others" remained a looming possibility for "later on" which was returned to every so often but one that remained a desire stumbling upon the material conditions and historicity of everyday practice.

\subsection{Engaging with the Un/Invited Others}

The project continued with a workshop where the participants engaged with a set of "seed stories," collected originally through a nationwide invitation for the public to write their stories about harassment and bullying at work. As part of our design-in-use approach, we selected and anonymized a set of these stories with which the participants would then continue to work, using different social media tools and different participatory methods so as to work with the contents and technologies in parallel.

The participants began to work with the seed stories in a workshop. They traced and imaged the stakeholders involved as well as the potential practices of intervention that could help in such cases and narrated them together in a shared wiki document. As they did so, the seed stories became enriched with imagined people and stakeholders, recommendations based on "good practices" and the user-practitioners' personal experiences. Importantly, while working with the real-life cases during the workshop, the participants' own entanglements with bullying interventions "jumped" and surged [16] into the present as embodied accounts of struggle and conflict. This meant that as the user-practitioners continued to engage with the stories during the workshops and later online, they engaged not only with the seed stories, but with a dynamic entanglement of participants, stories, wiki-entries, experiences, and affects. Through those entanglements a shared understanding emerged as to what it is to be engaged in bullying interventions in the workplace.

By gathering around the seed stories, the phenomenon of workplace bullying and harassment was reconfigured as an object of concern in a partial and particular manner. From the designer-researcher's perspective, within this flow of events, it did not seem ethically sustainable to "stick with" the vision of including a wide range of stakeholders but to engage with the concern that emerged through the process unexpectedly-to care about the practical work of intervening in the bullying and harassment which the participants encountered in their work.
The work with the seed stories materialized as a manageable manner of engaging with the "excluded others". The authentic stories brought the voice of the different stakeholders into the process in a way that did not challenge or put the participants at risk of conflict, and constructed a space for affirmation rather than contestation. In this process, the participants began to build collaboration around their shared experiences, which then, importantly, became the core of the collaboration. From the perspective of bullying and harassment, the design process unfolded as a flow of crowded encounters rich with histories, anticipations, decisions, affects, stories, present and absent bodies, commitments, and co-emerging issues through which workplace bullying and harassment reconfigured and came to matter as the object of concern.

\subsection{The Unfinished Business of Mattering}

The ways workplace bullying and harassment mattered and reconfigured were caught in the histories of union work, affectivity of intervention, and intentionality of the technologycentered project, entangled in the situated practices of design; their materiality, temporalities, discourses, and affects. Working with the emergent within these given frames taught us how as designers and researchers we are utterly-and perhaps uncomfortably- "in the middle" when committing to our ethicopolitical principles and fostering the formation of concerns. The ethical and political motivations entailed in our PD processsuch as tending to multiple voices and fostering democratic decision-making-reconfigured there in the middle of the materiality of the everyday practices of design as partial and unsettled.

In our pilot study, tied with the historicity of the project on the one hand and the flow of events on the other, the collaboration never expanded to include a wider range of stakeholders, nor did it go on to construct conditions for contestation. We never broadened our scope out from the comforts of the shared experiences among those who were already involved. From the perspective of developing bullying interventions, by not including the manifold stakeholders, such as those bullied, and by speaking for them instead of listening to them, it could be argued that this process, based on strict boundaries and shared understanding, reinforced the participants as the knowledgeable interventionists. It can also be argued that it reinforced the dichotomy between the "two sides" in the workplace, the employee and the employer, as there was no one to contest this division or make visible what is shared inbetween.

After the project ended, the work of the network continued but shifted toward more general concerns of workplace wellbeing, perhaps due to the organizational goals and priorities of the study center as the coordinator of the newly established network. The designer-researcher, in turn, returned to "wonder" [16] about the case from the perspective of bullying and violence. What was it that had side-lined the need to also critically address bullying and to tackle it by pushing practices and understandings forward and in new directions in order to make a difference? Thinking back to our case, the designer- 
researcher paid attention to, and reflexively engaged with, the situated dynamics of the design process. Through this openness to the emergent, she was sensitized to the tensions between the object of concern (the phenomenon of bullying and harassment) and its local materializations, and, in a way, learned-and unlearned-how care for the phenomenon of bullying and harassment can also materialize in ambiguous and partial ways. Engaging with the concern as it emerged through our process opened a window to the unexpected and unplanned that, nevertheless, mattered. In our PD case, what mattered was to construct conditions of care for the participating userpractitioners in their mutual work against workplace harassment and bullying.

\section{POLITICS OF MATTERING IN PD}

Ethics and politics are core tenets of $\mathrm{PD}$, inherited from its Scandinavian roots. They inform the practices of participation, and are maintained as goals and visions for ensuring "that the voice of marginalized groups and communities are heard in decision making processes that will affect them" [30:6]-an ethical and moral imprint in the ways socio-material and sociotechnical futures materialize in and through the practices of design and participation. Within the diversifying terrain of PD, this heritage has been re-enacted. "New forms of politics" [11:199-200] have been gestured in the ways PD's political focus has "moved out" from its traditional range of politics in design, participatory relations and mutual learning between stakeholders and designers to design as a political action through which the agendas of a community are explored and publics are constituted [10-12]. Design becomes not a space for constructing agreement, but an agonistic, adversarial one for plurality and contestation to be engaged with constructively [11, 31-33].

Our account of our PD case proposes an alternative way of imagining design as a space for political practices, and does so with the posthuman and new materialist politics of mattering.

Our study was about bullying and harassment in the workplace which meant we were engaged with an issue that is both ethical and political, and in a collaboration that took place as part of the political ecology of workplace and trade unionsan unmistakable connection to the political heritage of PD [34]. Nonetheless, our study was not about bringing disparate voices together to generate design friction [32] nor to reach consensus. Rather, our case reminds us that the ethical and political already exist in the design practices as the ethico-politics of mattering. Perhaps, in "unpacking" the politics of our story, we need to go beyond decisions, stakeholders, or even the political landscape and to slow down [35] and engage with the flows through which decisions, stakeholders, matters, and issues reconfigure. What comes to matter in the practices of design makes differences, shifting and swerving, taking the process in unexpected places.

Addressing politically important goals in, or through, PD is an uncertain and open-ended endeavor, and always also an ethical one. This challenges designers and researchers to rethink the ethics and politics of making a difference in PD as a process of engagement with the socio-material, affective, and entangled practices-assemblages of space, time, and matter-through which political goals reconfigure, become enacted and are coconstituted.

The ethico-politics outlined by Barad and Haraway open up to the multiple scales of politics entangled in the everyday practices of design, from technologies and design practices to the Things and concerns they help to address. This thinking also challenges us to rethink how the heritage of politically motivated PD, its values, ideals, and desires, come to matter as part of the motion of mattering, enabling us to value the ways this heritage reconfigures in the practices of design, but alsoperhaps more importantly-to open up to response-ably [26-29] engaging with its mattering.

By suggesting politics in the middle, we are not only reminding that politics are enacted in practice, but rather that the socio-material practices are always already political. The politics of mattering situate designers and researchers "in the middle of things" as it becomes impossible to disentangle or separate the historicity that brought us here and the futures that might yet be. This relationality is a material-discursive relationality of "moments," "places," and "things" [36] in their ongoing reconfiguring, and, in this reconfiguring, we are/were already entangled. This is the gist of the "always-relational" politics of mattering.

\section{AN AFTERTHOUGHT}

Unpacking politics hardly ends where the project ends. This paper traces one such mattering by way of returning to our PD case from the perspective of workplace bullying, and by opening up to the uninvited and excluded so as to remain accountable for the mattering of our practices, the ethics and politics of engaging, telling stories, and making returns.

Our study works to remind PD community of the ways we as designers and researchers are enmeshed in the pasts and futures of the technologies and practices we design and the concerns we address-always bound by the material conditions of the present. Our paper contemplated the troubles of addressing ethicopolitical issues. This seems particularly important in a time when designers and researchers continue to engage with diverse issues and concerns. Regardless of how and in what ways we take a stand in our engagements-a stand against bullying, a stance for polyvocality, as we tried to do in our design practices-we are and were always already engaged and entangled in the motion of mattering ongoing in messy, unpredictable and indeterminate ways. Times for categorical rights and wrongs are long past, and it is now timely to strive for ways to embrace the ethico-politics in our practices.

\section{ACKNOWLEDGMENTS}

We wish to thank the Openrisk project and most importantly the participants in our case for their valuable contribution. Karasti acknowledges The Academy of Finland for grant \#285903.

\section{REFERENCES}

[1] Helena Karasti, Volkmar Pipek, and Geoffrey C. Bowker. 2018. An afterword to "Infrastructuring and Collaborative Design." Comput Supp Coop W F 27, 2 (Jan 2018). DOI: https://doi.org/10.1007/s10606-017-9305-x 
[2] Diana Coole and Samantha Frost. 2010. Introducing the new materialisms. In New materialisms: Ontology, agency, and politics, Diana Coole and Samantha Frost (eds.). Duke University Press, Durham, NC, 1-43.

[3] Lucy Suchman. 2007. Human-machine reconfigurations: Plans and situated action. Cambridge University Press, Cambridge.

[4] Lucy Suchman. 2002. Located accountabilities in technology production. Scandinavian fournal of Information Systems 14, 2, Article 7 (2002), 91-105

[5] Waltraud Ernst, Corinna Bath, and Marja Vehviläinen. 2017. Political objects: Prescriptions, injustices and promises of material agents. International fournal of Gender, Science and Technology 9, 2 (Nov 2017), 77-79. Retrieved from http://genderandset.open.ac.uk/index.php/genderandset/article/view/546

[6] Sisse Finken. 2005. Methods as technologies for producing knowledge. Doctoral dissertation. Roskilde University, Roskilde, Denmark.

[7] Ann Light and Yoko Akama. 2014. Structuring future social relations. In Proceedings of the 13th Participatory Design Conference: Research Papers (PDC '14), ACM Press, New York, NY, 151-160. DOI: https://doi.org/10.1145/2661435.2661438

[8] Helena Karasti. 2014. Infrastructuring in Participatory Design. In Proceeding of the 13th Participatory Design Conference: Research Papers (PDC '14). ACM Press, New York, NY, 141-150. DOI: https://doi.org/10.1145/2661435.2661450

[9] Helena Karasti and Anna-Liisa Syrjänen. 2004. Artful infrastructuring in two cases of community PD. In Proceedings of the eighth conference on Participatory design (PDC '04). ACM Press, New York, NY, 20-30. DOI: https://doi.org/10.1145/1011870.1011874

[10] Pelle Ehn, Elisabet M Nilsson, and Richard Topgaard. 2014. Introduction. In Making futures: Marginal notes on innovation, design, and democracy, Pelle Ehn, Elisabeth M. Nilsson and Richard Topgaard (eds.). MIT Press, Cambridge, MA, 1-13.

[11] Carl DiSalvo, Andrew Clement, and Volkmar Pipek. 2013. Communities: Participatory Design for, with and by communities. In Routledge international handbook of Participatory Design, Jesper Simonsen and Toni Robertson (eds.) Routledge, London, 182-209.

[12] Erling Bjögvinsson, Pelle Ehn, and Per-Anders Hillgren. 2012. Design things and design thinking: Contemporary Participatory Design challenges. Des. Issues 28, 3 (July 2012), 101-116. DOI: https://doi.org/10.1162/DESI_a_00165

[13] Mette Agger Eriksen. 2012. Material matters in co-designing: formatting \& staging with participating materials in co-design projects, events \& situations. Doctoral dissertation. Malmö University, Malmö, Sweden. Retrieved from http://hdl.handle.net/2043/13674

[14] Tone Bratteteig and Guri Verne. 2012. Disentangling for Autonomy: Understanding the Sociomaterial Practices of Public Services. In Nordic Contributions in IS Research. SCIS 2012. Lecture Notes in Business Information Processing, vol 124. Springer, Berlin, Heidelberg, 56-75. DOI: https://doi.org/10.1007/978-3-642-32270-9_4

[15] Suvi Pihkala and Helena Karasti. 2016. Reflexive Engagement: Enacting Reflexivity in Design and for "Participation in Plural." In Proceedings of the 14th Participatory Design Conference: Research Papers - Full papers Vol 1. (PDC '16). ACM Press, New York, NY, 21-30. DOI: http://doi.acm.org/10.1145/2940299.2940302

[16] Suvi Pihkala. 2018. Touchable matters: Reconfiguring sustainable change through participatory design, education, and everyday engagement for nonviolence. Doctoral dissertation. University of Oulu, Oulu, Finland. Retrieved from http://urn.fi/urn:isbn:9789526218434

[17] Christina Mörtberg, Dagny Stuedahl, and Pirjo Elovaara. 2010. Designing for sustainable ways of living with technologies. In Exploring digital design. Multidisciplinary design practices, Ina Wagner, Tone Bratteteig and Dagny Stuedahl (eds.). Springer-Verlag, London. DOI: https://doi.org/10.1007/978-1-84996-22309

[18] Kristina Lindström and Åsa Ståhl. 2016. Becoming response-able stakeholders. In Proceedings of the 14th Participatory Design Conference on Short Papers, Interactive Exhibitions, Workshops (PDC '16). ACM Press, New York, NY, 4144. DOI: https://doi.org/10.1145/2948076.2948086

[19] Kristina Lindström and Åsa Ståhl. 2016. Politics of inviting: Co-articulations of issues in designerly public engagement. In Design anthropological futures: Exploring emergence, intervention and formation, Rachel Charlotte Smith, Kasper Tang Vangkilde, Mette Gislev Kjaersgaard, Ton Otto, Joachim Halse and Thomas Binder (eds.). Bloomsbury Academic, London, 182-197.

[20] Ann Light and Yoko Akama. 2012. The Human touch: Participatory practice and the role of facilitation in designing with communities. In Proceedings of the 12th Participatory Design Conference: Research papers (PDC '12). ACM Press, New York, NY, 61-70. DOI: https://doi.org/10.1145/2347635.2347645

[21] Yoko Akama. 2014. Attuning to Ma (between-ness) in designing. In Proceedings of the 13th Participatory Design Conference: Short Papers, Industry Cases, Workshop Descriptions, Doctoral Consortium papers, and Keynote abstracts (PDC '14). ACM Press, New York, NY, 21-24. DOI: https://doi.org/10.1145/2662155.2662179

[22] Jouko Heikkilä, Asta Bäck, Anna-Mari Heikkilä, Päivi Hämäläinen, Pirjo Näkki, Kaarin Ruuhilehto, et al. 2012. Sosiaalinen media turvallisuutta ja työhyvinvointia edistävien yhteisöjen tukena. Openrisk-hankkeen loppuraportti
(Social media as a support to communities promoting safety and well-being at work. Openrisk. Final report). Espoo: VTT Technical Research Centre of Finland. Retrieved from http://www.vtt.fi/publications/index.jsp

[23] Suvi Pihkala and Helena Karasti. 2013. Reflexive Engagement - Reflexive Orientation for Participatory Design. In Proceedings of the IADIS International Conference ICT, Society and Human Beings 2013. Piet Kommers, Claire Gauzente, (eds.). IADIS Press, 85-92.

[24] Bruno Latour. 2005. From realpolitik to dingpolitik or how to make things public. In Making things public: Atmospheres of democracy, Bruno Latour and Peter Weibel (eds.). MIT Press, Cambridge, MA, 14-41.

[25] Gilles Deleuze and Felix Guattari. 1989. A thousand plateaus: Capitalism and schizophrenia (B. Massumi, Trans.). University of Minnesota Press, Minneapolis, MN.

[26] Karen Barad. 2007. Meeting the universe halfway: Quantum physics and the entanglement of matter and meaning. Duke University Press, Durham, NC.

[27] Donna Haraway. 2008. When species meet. Minnesota University Press, Minneapolis, MN.

[28] Donna Haraway. 2016. Staying with the trouble. Making kin in the Chthlucene. Duke University Press, Durham, NC.

[29] Donna Haraway. 2012. Awash in urine: DES and Premarin ${ }^{\circledR}$ in multispecies response-ability. WQS Women's Quaterly 1 \& 2, 40 (Spring/Summer 2012), 301-317. DOI: https://doi.org/10.1353/wsq.2012.0005

[30] Toni Robertson and Jesper Simonsen. 2013. Participatory Design: An introduction. In Routledge international handbook of Participatory Design, Toni Robertson and Jesper Simonsen (eds.). Routledge, London, 1-17.

[31] Per Anders Hillgren, Anna Seravalli, and Anders Emilson. 2011. Prototyping and infrastructuring in design for social innovation. CoDesign 7, 3-4 (Nov 2011), 169-183. DOI: https://doi.org/10.1080/15710882.2011.630474

[32] Laura Forlano and Anijo Mathew. 2014. From design fiction to design friction: Speculative and participatory design of values-embedded urban technology. 7 . Urban Technology 21, 4 (Dec 2014), 7-24. DOI: https://doi.org/10.1080/10630732.2014.971525

[33 Anders Emilson and Per-Anders Hillgren. 2014. Connecting with the powerful strangers: From governance to agonistic design things. In Making futures: Marginal notes on innovation, design, and democracy, Pelle Ehn, Elisabeth M. Nilsson and Richard Topgaard (eds.). MIT Press, Cambridge, MA, 63-84.

[34] Finn Kensing and Joan Greenbaum. 2013. Heritage: Having a say. In Routledge international handbook of Participatory Design, Jesper Simonsen and Toni Robertson (eds.). Routledge, London, 21-36.

[35] Zsuzsa Millei and Pauliina Rautio. 2017. "Overspills" of research with children An argument for slow research. Child Geogr 15, 4 (2017), 466-477. DOI: https://doi.org/10.1080/14733285.2016.1277182

[36] Karen Barad. 2017. No small matter: Mushroom clouds, ecologies of nothingness, and strange topologies of spacetimemattering. In Arts of living on a damaged planet: Ghosts and monsters of the Anthropocene, Anna Lowenhaupt Tsing, N. Bubandt, E. Gan and H. A. Swanson (eds.). Minnesota University Press, Minneapolis, MN, 103-120. 